\title{
A delphinid petrosal bone from a gravesite on Ahu Tahai, Easter Island: taxonomic attribution, external and internal morphology.
}

\author{
Orliac Maëva J1*, Orliac Catherine ${ }^{2}$, Orliac Michel C. ${ }^{2}$, Hautin Antoine ${ }^{1}$ \\ ${ }^{1}$ Equipe de Paléontologie, Institut des Sciences de l'Évolution de Montpellier (UMR 5554, CNRS, UM, IRD, EPHE), c.c. 064, Université Montpellier, \\ place Eugène Bataillon, F-34095 Montpellier Cedex 05, France \\ ${ }^{2}$ UMR 7041 Archéologies et Sciences de l'Antiquité, Université Paris 1 Panthéon-Sorbone, Université Paris X, Nanterre, France \\ ${ }^{*}$ Corresponding author: maeva.orliac@umontpellier.fr
}

\begin{abstract}
In this contribution, we describe the external and internal morphology of a delphinid petrosal bone collected from Ahu Tahai, a burial site located on the Southwestern coast of Easter Island, at Hangaroa. We discuss the taxonomic attribution of this archaeological item and describe its internal structures based on $\mu C T$ data, including the bony labyrinth and the nerve and vein patterns. Identification of the nerves exists lead us to relocate the identification of the foramen singulare in delphinid petrosals.
\end{abstract}

Keywords: bony labyrinth, petrosal, Rapanui, Stapes, vestibulo cochlear nerve

Submitted:2019-07-02, published online:2020-31-03. https://doi.org/10.18563/journal.m3.91

\section{INTRODUCTION}

Marine mammals in general and cetaceans in particular arouse a particular interest for human societies from prehistoric/historic times to modern days. It is particularly the case for sailor peoples such as Polynesians (Bianucci \& Landini 2016). Easter Island (Rapanui) is one of the most remote and isolated island on the planet, located $3700 \mathrm{~km}$ away from Chilean coasts and approximately $4000 \mathrm{~km}$ from Tahiti shores. Polynesian settled on the island around $1000 \mathrm{AD}$ (Steadman et al. 1994). Rapanui is renowned for bearing gigantic anthropomorphic statues. The most impressive monumental structures of the island are large platforms (ahu), the cladding of which are sometimes formed by gigantic stones. Most of the 250 ahu spread around the island are built parallel to the sea shore (Bahn \& Flenley 2017).

Around fifty ahu bear gigantic stone statues (moai). Tombs are buried in the structure of these monuments or in their immediate vicinity. On the ocean's side, sometimes directly contacting the ahu, a "crematorium" is uplifted on the narrow strip of land that separates the marine front of the monument from the shore. It consists in a rectangular cist of about two meter long, delineated by stones peeking out twenty to thirty centimeters above the ground level. This cist, filled with soil and stones, contains rare human bones - cremated or not - associated to diverse offerings, usually laid in these sacred places and in sepultures: mostly small fragments of red tufa coming from one of the major sanctuary of the island (Puna Pau), mollusks shells, fish bones and numerous little marine pebble (Orliac \& Orliac 2018a, 2018b). The Tahai area is one of the most important monumental assemblage of the island, located on the southwestern shore, near Hangaroa (Fig. 1A-C). The construction of ahu Tahai is dated between the 12th and 13th century (Shepardson 2013:126); it was restored by William Mulloy and Gonzalo Figueroa in 196970 (Fig. 1B). Within Tahai area, Mulloy (1970:32) described the crematorium of the ahu Vai Uri: "This structure was covered with about sixty centimeters of earth and rubble. It has not been restored and appears to be nearly in its original condition, except for several missing stones at it south end. Unlike the condition at some other crematoria on the island, very few burned human bones were found associated with this structure". During a field mission in 1995, a visit of the ahu Vai Uri site (it was then allowed to go around the ahu), led C. and M.C. Orliac to witness that the crematorium was suffering from both gully erosion and visitors curiosity: stones of the monument's belt were missing on the ocean's side and artifacts were slipping out by these breaches. Among them, exposed on the surface of the ground, one cetacean petrosal bone (AT1) was collected in situ by C. and M.C. Orliac (Fig. 1D). The petrosal bone is part of the mammalian skull. It shelters the organs of hearing and balance and gives passageway to nerves and blood vessels. In cetaceans, the petrosal bone has the particularity of being very dense and completely isolated from the other bones of the skull by wide sinuses that permit sound insulation in relation to underwater hearing (Nummela et al. 2004, 2007). Therefore, cetacean petrosals are easily preserved and found isolated in paleontological and archeological sites because of their high density and detachment from the other bones of the skull. Mammal remains on Rapa Nui usually consist in rat remains, and the occurence of a large mammal bone in the ahu Vai Uri therefore presents a particular interest. Nine cetacean species have been observed along Rapanui coasts during the past century (updated listing by Hucke-Gaete et al. 2014): three species of Balaenopteridae [Balaenoptera musculus (blue whale), Balaenoptera bonaerensis (Antartic minke whale), Megaptera novaeangliae (humpback 

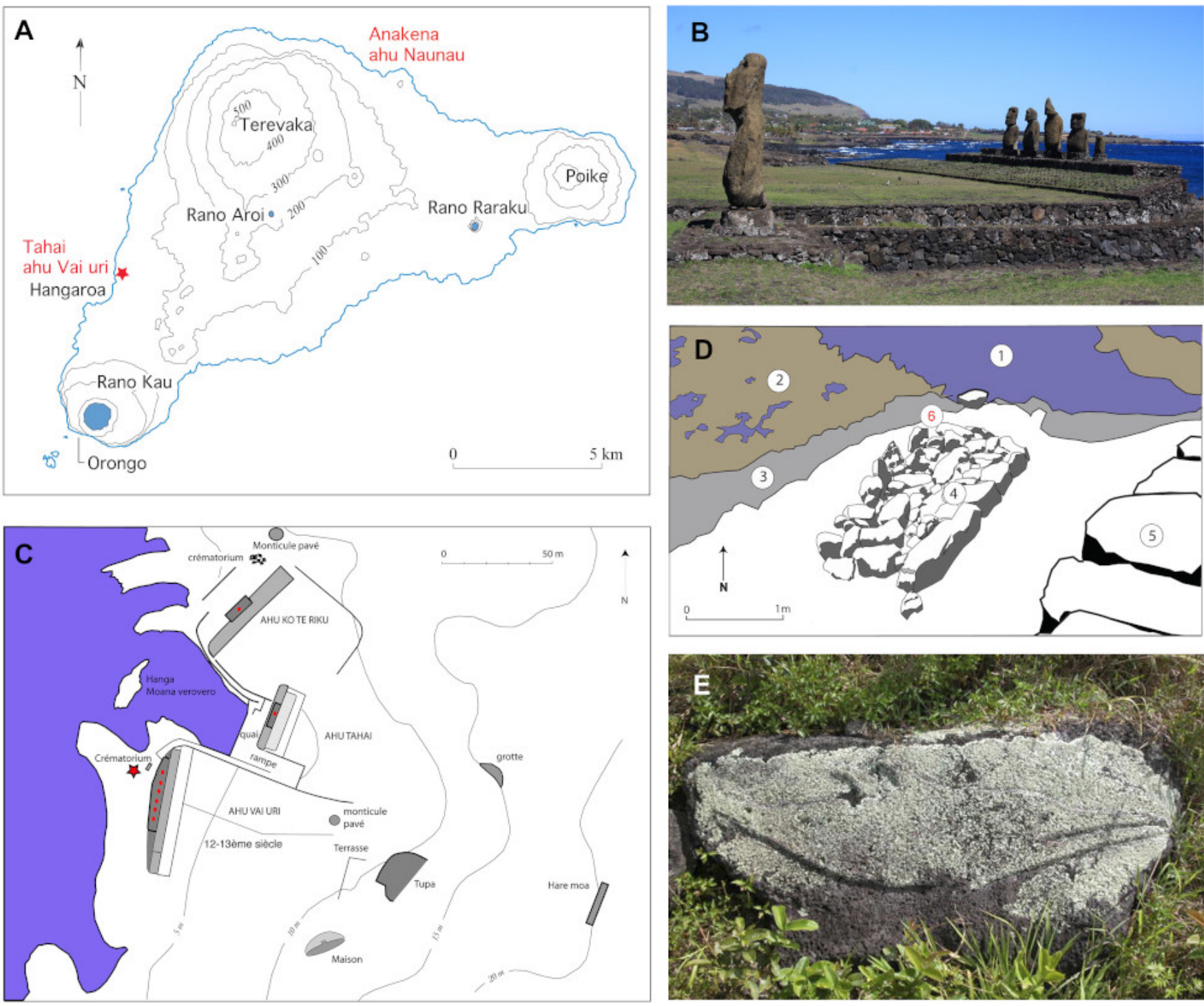

Figure 1. Location and A) Map of Rapa Nui (Easter Island), localization of the sites mentioned in the text appears in red; Southern part of the monumental complex of Tahai. B) In the foreground lies the moai of ahu Tahai, in the second ground the Vai uri ahu with its five moai, in the background the village of Hangaroa ( $)$ M. C. Orliac; C) plan of the monumental complex of Tahai, after William Mulloy (1970). The Vai Uri ahu is located in the Southern part of the complex; the red star indicates the location of the crematorium where the petrosal was collected. D) Drawing of the Vai Uri crematorium realized after a photograph by William Mulloy (1970). 1, ocean; 2, reef at low tide; 3, sloping shore; 4, crematorium; 5, back façade of the ahu; 6, approximate location of the petrosal when collected. Since the momument's building, the shore receded from several meters. E) bas-relief representing a longirostre dolphin, length 2.13 meters, Anakena bay (C) M.C. Orliac. 


$\begin{array}{ll}\text { Model IDs } & \text { Description } \\ \text { M3\#420_AT1 } & \text { Stapes } \\ \text { M3\#421_AT1 } & \text { Petrosal bone } \\ \text { M3\#422_AT1 } & \text { In situ bony labyrinth } \\ \text { M3\#423_AT1 } & \begin{array}{l}\text { Bony labyrinth and associated nerves and } \\ \text { blood vessels }\end{array}\end{array}$

Table 1. List of models derived from the delphinid petrosal AT1 from the Sebastian Englert Museum, Hanga Roa, Rapanui.

whale)], one Physeteridae [Physeter macrocephalus (sperm whale)]; two species of Ziphiidae [Ziphius cavirostris $(\mathrm{Cu}-$ vier's beaked whale), and Mesoplodon densirostris (Blainville's beaked whale)], and three species of Delphinidae [Pseudorca crassidens (false killer whale), Globicephala sp. (unidentified pilot whale), Tursiops truncatus (bottlenose dolphin)]. In addition to these direct observations, osteological remains of the delphinidae Delphinus delphis (the common dolphin) have been reported from the archeological site of Ahu Naunau, Anakena (Steadman et al. 1994), including several petrosal bones. In this contribution, we describe the external and internal morphology (including bony labyrinth, and nerve and vein patterns) of the petrosal bone AT1 and discuss the identification of the different components of the internal acoustic meatus in delphinids based on vestibulo-cochlear nerves pathways. The taxonomic attribution of AT1 is finally discussed and the presence of delphinid remains in the ahu Vai Uri is put in the general historical context of the Rapanui Island.

\section{METHODS}

For descriptions, the orientation of the petrosal is simplified against its position in the basicranium, with the anteroposterior axis corresponding to the greatest length of periotic. We mainly follow the nomenclature used by Mead and Fordyce (2009) for petrosal morphology, that of Ekdale (2013) and Orliac et al. (2017) for internal structures terminology. Measurements of the external surface of the petrosal were taken with a caliper and follow the protocol as decribed in Kasuya (1973) and Bianucci (1996). The specimen was scanned with a resolution of $18 \mu \mathrm{m}$ using the Skyscan 1076 in vivo $\mu$ CT scanner of the Montpellier Ressources Imagerie platform housed in the Université de Montpellier. We virtually extracted the stapes and the digital structure of the endocast of the bony labyrinth and of the cochlea's innervation and irrigation, using the segmentation tools of AVIZO 9.0 (Visualization Sciences Group). Associated 3D models are provided for the stapes, petrosal, in situ bony labyrinth, and bony labyrinth with associated nerves and blood vessels (Table 1). The segmentation process was performed slice-by-slice manually with the limited range only option of the brush tool of AVIZO 9.0. The right petrosal bone AT1 is housed in Sebastian Englert Museum, Hanga Roa (Easter Island).

\section{abbreviations}

IRSNB: Institut Royal des Sciences Naturelles de Belgique.

\section{DESCRIPTIONS}

\section{Systematics}

\author{
Order Cetacea Brisson, 1762 \\ Suborder Odontoceti Flower, 1867 \\ Familly Delphinidae Gray, 1821 \\ Subfamilly Delphininae Le Duc, 1997 \\ Morphotype Stenella/Delphinus
}

\section{External morphology of the petrosal bone}

The petrosal AT1 is perfectly preserved with the stapes in functional position in the fenestra vestibuli. Petrosal measurements are presented in Table 2 .

In dorsal view (Fig. 2A), the general shape of the petrosal bone is globose with short anterior and posterior processes and a pars cochlearis bulging medially. The internal acoustic meatus is elliptical (major axis anteroposteriorly oriented). The opening of facial canal is anteromedialy located, close to the tractus spiralis foraminosus. This part of the facial canal is located quite laterally in the internal acoustic meatus and the crista transversa is narrow and located low down in the internal acoustic meatus. The tractus spiralis foraminosus and the area cribrosa media (passageway to the saccular branch of the vestibulocochlear nerve) are located deeply in the internal auditory meatus. The external aperture for the vestibular aqueduct is located posterolaterally to the tractus spiralis foraminosus in a small slit. Striations are present on the bone posterior to the aperture. The cochlear aqueduct opens in a small pit, located dorsomedially, and bordered posteriorly by a blunt tuberosity. The medial-most surface of the bone, on the pars cochlearis, is rugose and punctuated by several small holes. Few depressions are also present on the mastoid portion of the bone, on the lateral border of the internal auditory meatus.

In ventral view (Fig. 2B), the lateral outline of the petrosal is sigmoidal. The anterior process is rectangular in cross-section and is oriented anteromedially. On its apex, the anterodorsal and anteroventral angles are small and blunt. The fovea epitubaria is divided into two slightly concave areas which are anterodorsaly elongated. A broad parabullary ridge delimits the lateral margin of the anterior process. Posterior to the fovea epitubaria, lies a small and deeply concave fossa for the malleus that opens posteromedially. The triangular broken base of the anterior pedicle separates these two shallow concavities. A broad V-shape epitympanic hiatus separates the anterior process from the posterior one. The posterior bullar facet is a trapezoid in shape and slightly concave surface. Its posteromedial angle is rounded, while the posterolateral angle is pointed. The posterior part of the posterior bullar facet is scarred by deep parallel striations, oriented on the long axis of the posterior process. The pars cochlearis is globose and anteroposteriorly stretched. The fenestra cochleae is large and opens posteromedially. The fenestra vestibuli is elliptical and covered by the in situ stapes. Both fenestrae are separated by a wide crista interfenestralis.

In medial (Fig. 2C) and lateral views (Fig. 2D), the ventral margin of the parabular ridge and of the posterior bullar facet 

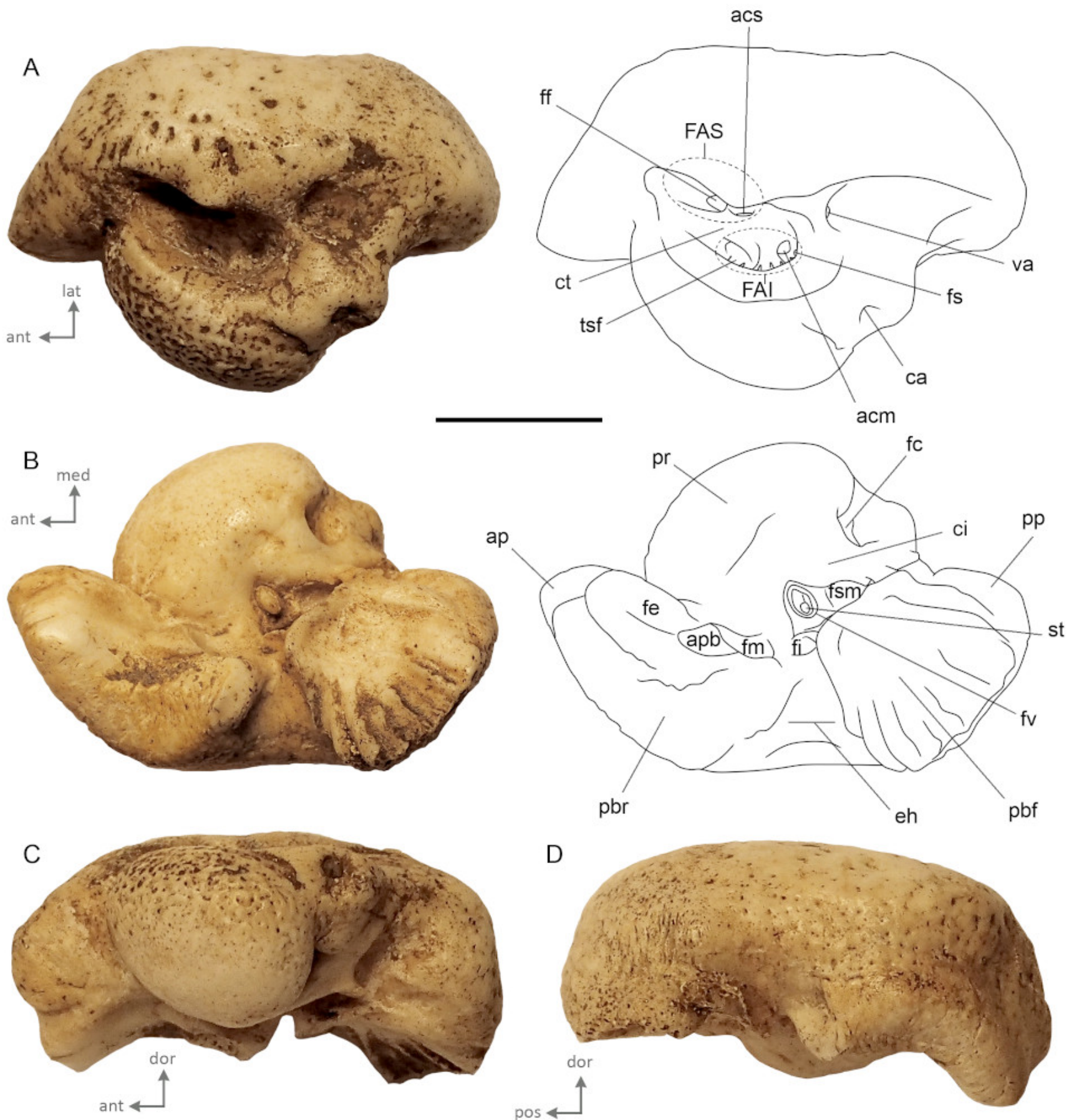

Figure 2. External morphology of AT1 illustrated in A) dorsal, B) ventral, C) medial, D) lateral views. Abbreviations: acm, area cribrosa media; acs, area cribrosa superior; ap, anterior process; apb, anterior pedicle basis; ca, cochlear acqueduct; ci, crista interfenestralis; ct, crista transversa; eh, epitympanic hiatus; FAI, foramen acusticum inferius; FAS, foramen acusticum superius; ff, facial foramen; fe, fovea epitubaria; fc, fenestra cochleae; fi, fossa incudis; fm, fossa for the malleus; fs, foramen singulare; fsm, fossa for stapedial muscle; fv, fenestra vestibuli; pbf, posterior bullar facet; pp, posterior process; pbr, parabullar ridge; pr, promontorium; st, stapes; tsf, tractus spiralis foraminosus; va, vestibular acqueduct. Scale bar $=1 \mathrm{~cm}$. 


\begin{tabular}{|c|c|c|c|c|c|c|}
\hline & AT1 & $\begin{array}{l}\text { Stenella } \\
\text { coeruleoalba } \\
\text { IRSBN } 35187\end{array}$ & $\begin{array}{l}\text { Delphinus } \\
\text { delphis } \\
\text { IRSNB } 33388\end{array}$ & $\begin{array}{l}\text { Tursiops } \\
\text { truncatus } \\
\text { IRSNB } 20138\end{array}$ & $\begin{array}{l}\text { Tursiops } \\
\text { truncatus } \\
\text { IRSNB 20139 }\end{array}$ & $\begin{array}{l}\text { Tursiops } \\
\text { truncatus } \\
\text { IRSNB } 40240\end{array}$ \\
\hline GLP & 29.5 & 28.7 & 30 & 39.7 & 37.6 & 32 \\
\hline GWP & 21.5 & 20.6 & 21.9 & 26.3 & 25.4 & 22.8 \\
\hline WPUT & 20.2 & 19.6 & 20.5 & 24.1 & 24.1 & 20.6 \\
\hline GTP & 14.2 & 13.8 & 13.5 & 20.4 & 28.3 & 15.5 \\
\hline TPUT & 11 & 10.8 & 9.8 & 17.1 & 15.1 & 11.7 \\
\hline LPC & 17.2 & 18 & 17.7 & 19.3 & 18.7 & 19.4 \\
\hline ТPC & 10.5 & 9.4 & 9.4 & 13 & 12.5 & 11 \\
\hline LAPP & 17.3 & 17.5 & 18.3 & 21.1 & 19.6 & 17.2 \\
\hline LPPP & 11.8 & 11.6 & 12.3 & 17.4 & 17.7 & 13.1 \\
\hline LVT & 14.2 & 14.8 & 15.2 & 17.1 & 16.1 & 14.2 \\
\hline
\end{tabular}

Table 2. Measurements (in mm) of the petrosal bone from ahu Vai Uri and of petrosal bones of the dephinids Stenella coeruleoalba, Delphinus delphis, and Tursiops truncatus from IRSNB collections. Abbreviations: GLP, greatest length of periotic; GWP, greatest width of periotic; WPUT, width of periotic at level of upper tympanic aperture; GTP, greatest thickness of periotic; TPUT, thickness of periotic at level of upper tympanic aperture; LPC, length of pars cochlearis; TPC, thickness of pars cochlearis; LAPP, length of anterior process of periotic; LPPP, length of posterior process of periotic; LVT, length of ventral tuberosity to ventral swelling of periotic.

are concave. The globose promontorium protrudes ventrally; its ventral surface is smooth while its dorsal part is punctuated by several pits, suggesting an important vascularization of the bone.

\section{Stapes}

AT1 preserves an in situ stapes, closely apposed against the fenestra vestibuli. The stapes consists of three parts: the head or capitulum, the body, which is composed of two crura (the anterior crus and the posterior crus), and the stapes basis or footplate (Fig. 3). The morphology of the stapes of AT1 is very close to that of Tursiops illustrated by Mead and Fordyce (2009:fig.26m). The head of the stapes is broad and carries a wide articular facet for contact with the lenticular process or crus longum of the incus (Fig. 3E; Kellogg 1927:29, 31). The muscular process of the stapes, located on the posterior crus, is blunt and wide, like in Tursiops. It serves as attachment site for the musculus stapedius, also attached to the processus muscularis stapedis lying in the area of the posterior wall of the tympanum. The shaft of the stapes in placental mammals generally presents a central cavity, the foramen intercrurale, which provides passageway (at least in embryos) to the stapedial artery. In AT1, the body is particularly osteosclerotic and there is no trace of a foramen intercrurale, except maybe for a slight depression on the medial surface (Fig. $3 \mathrm{~A})$. In lateral view, the stapes is only slightly asymmetric, with the anterior crus longer than the posterior one. The footplate of the stapes, articulating with the periotic at the fenestra vestibuli, is oblong with a stapedial ratio of 1.5 (footplate length $=2.25$ $\mathrm{mm}$; footplate width $=1.47 \mathrm{~mm}$ ). It is concave on the vestibular face; this concavity is similar to what is observed in Tursiops. However, the middle of the footplate is flat (Fig. 3D-F). The concavity of the footplate in cetacean is traditionally called "umbo" (e.g., Kellogg 1927; Fleischer 1976), which, by definition, refers to a convex surface, such as a shield for example. We therefore chose not to use this term here. The edges of the footplate are thick; in medial view, the profile of the articular surface of the footplate is straight, whereas in lateral view it is much more sigmoid. The same slightly asymmetric profile of the stapes is observed in other published delphinid specimens (e.g. Doran 1876, pl. LXII 2; Bianucci et al. 2009:fig.6J).

\section{Internal structures of the petrosal bone Bony labyrinth.}

The bony labyrinth of AT1 shows the classical morphology described in delphinids for Tursiops truncatus (e.g. Ekdale 2013:fig.30), with a reduction of the size of the vestibular apparatus compared to the cochlea, a loosely coiled cochlea with a reduced number of spiral turns, a very high basilar ridge and a long extension of the secondary bony lamina (Fig. 4, Table 3). The total volume of the bony labyrinth of AT1 equals 91 $\mathrm{mm} 3$, with a volume of the cochlea of $84 \mathrm{~mm} 3$ (92\% of the total volume). Consistently with petrosal size difference, the total volume of AT1 is inferior to that of T. truncatus (volume bony labyrinth $=168 \mathrm{~mm} 3$, Ekdale 2013:tab. 2-4; Churchill et al. 2016). Like in T. truncatus, the lateral canal is the longest of the semicircular canals. Unfortunately, to our knowledge, the measurements and morphology of the bony labyrinth of Stenella and Delphinus remain undescribed and are unavailable for comparison for the present study.

\section{Vestibulocochlear nerve pathways.}

The facial nerve (cranial nerve VII) and the vestibulocochlear nerve (cranial nerve VIII), constitute the two cranial nerves that enter the internal acoustic meatus of mammals. The vestibulocochlear nerve divides into two main branches: i) the vestibular part, distributed to the ampullae of the semicircular ducts (ampullar branches) and to the maculae of the utricle and saccule (utricular and saccular branches), and ii) the cochlear part spreading to the spiral ganglion (Barone \& Bortolami 2004). We reconstructed the pathways of the vestibulo cochlear nerve of AT1. The pathway for ampullar branch emerging from the ampulla of the posterior semicircular canal, that for the saccular branch, and that carrying the nerves from the utricule and from the anterior and lateral semicircular canal ampullae, are clearly identifiable on our reconstruction (Fig. 5). They originate from 

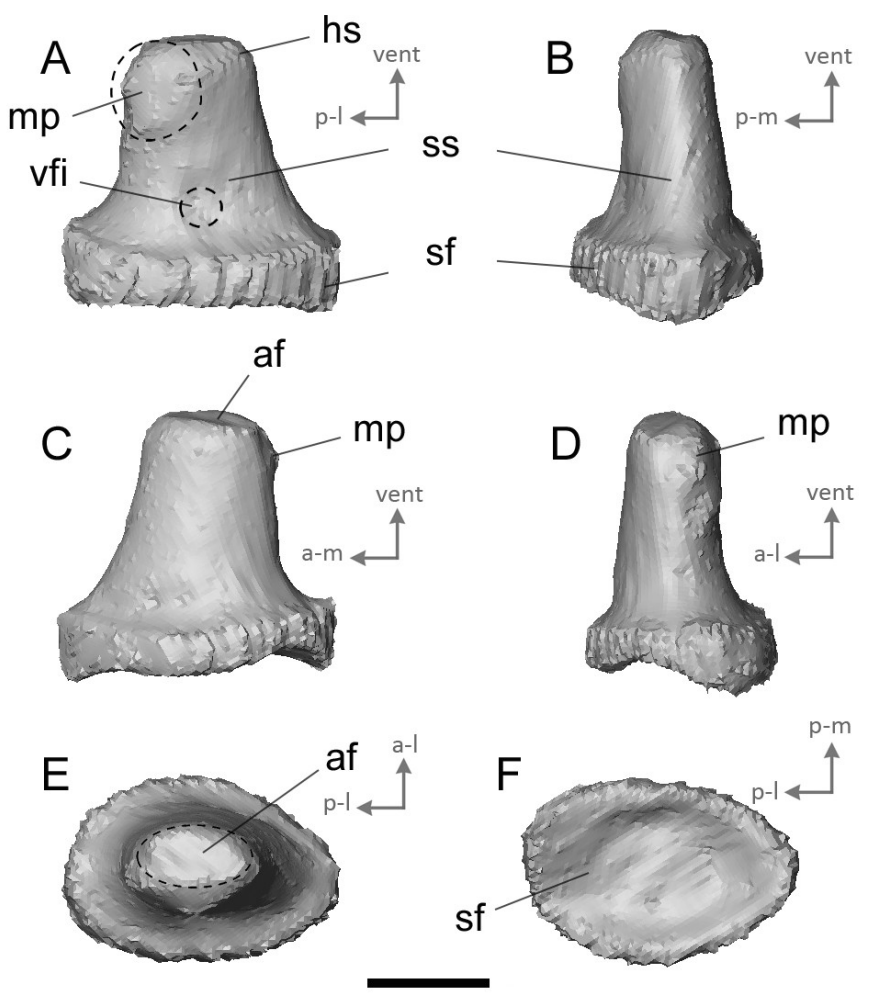

Figure 3. External morphology of the stapes of AT1, illustrated in A, medial; B, anterior; C, lateral; D, posterior; $\mathbf{E}$, ventral; F, dorsal, views. Abbreviations: hs, head of the stapes; ss, shaft of the stapes; sf, stapedial footplate; mp, muscular process; af, articular facet for the lenticular process; vfi, vestige of foramen intercrurale. Scale bar $=1$ $\mathrm{mm}$.

the posterior ampulla, the spherical recess and the elliptical recess respectively. In the foramen acusticum inferius of the petrosal, the tractus spiralis foraminosus is pierced by several foramina giving a passageway for nerve fibers connecting the cochlear part of the vestibulocochlear nerve and the spiral ganglion housed in the spiral canal (canalis spiralis modioli) (Fig. 5B). Partial breakage of the tractus spiralis foraminosus of the modiolus prevents us to reconstruct the fibers network in its entirety. Yet a particularly large tractus connect the anterior-most part of the spiral ganglion, close to the proximal-most part of the basal turn (Fig. 5D). Unfortunately, the spiral canal (housing the spiral ganglion) cannot be reconstructed in its entirety due to breakage of the primary bony lamina (lamina spiralis ossea primaria) at around $3 / 4$ of the basal turn. The spiral canal is clearly bigger than that of the vestibulocochlear nerve reconstruction of the extinct terrestrial artiodactyl Diplobune minor (Orliac et al. 2017:fig.6).

\section{Blood vessels.}

Only the widest, well isolated blood vessels associated to the cochlea could be reconstructed (Fig. 6). Indeed, some of their pathway might run directly inside the cochlear canal and does not leave imprints on the cast of the bony labyrinth, and/or, some are impossible to disentangle from the nervous fibers' pathway (e.g. modiolar artery). Only the pathway of the spiral

$\begin{array}{ll}\text { Tursiops truncatus } & \text { AT1 } \\ 168 & 91 \\ 157 & 84 \\ 34.42 & 25.54 \\ 28.14 & 23.23 \\ 11.13 & 9.44 \\ 4.38 & 4.16 \\ 8.60 & 7.46 \\ 1.94 & 1.55 \\ 0.76 & 0.65 \\ 4.96 & 5.00 \\ 1.75 & 1.75 \\ 4.14 & 3.71 \\ 4.35 & 3.71 \\ 4.61 & 4.38\end{array}$

Table 3. Measurements (in $\mathrm{mm}, \mathrm{mm} 2$ and $\mathrm{mm} 3$ ) of the bony labyrinths of the petrosal bone from ahu Vai Uri, and of Tursiops truncatus. Abbreviations: VT, total volume of the bony labyrinth; VC, volume of the cochlea (including cochlear aqueduct); Cl, cochlear canal length; Cw, cochlear width; FC, area of the fenestra cochlearis; GAN, maximal radius of the spiral ganglion canal; ITD, inter-turn distance; SBL, length of the secondary bony lamina; W2, shorter diameter of the basal turn, perpendicular to $\mathrm{Cw}$; \#T, number of turn of the cochlear canal. VT and VC for T. truncatus from Ekdale (2013), other measurements for this taxon from Churchill et al. (2016).

modiolar vein could be reconstructed. The vein pattern in AT1 appears to be strikingly different from that of the pig described by Shambaugh (1903) and that virtually reconstructed for the extinct artiodactyl Diplobune minor (Orliac et al. 2017). Indeed, compared to the two latter terrestrial artiodactyls, which exhibit a greater number of cochlear turns, there is no trace of posterior spiral vein (Vena spiralis posterior) collecting blood from the distalmost part of the cochlea. The only collecting branch observed is here recognized as the spiral modiolar vein. It empties in the cochlear aqueduct vein (Vena canaliculi cochleae), whose base only is visible as it fuses with the space of the cochlear aqueduct. The outer wall of the basal turn of the cochlear canal does not show any imprints of collecting venules which have been running inside the cochlear canal, as illustrated on Figure $6 \mathrm{C}$. The veins of the semicircular canals and of the vestibule are collected into the anterior and posterior vestibular veins in the pig (Shambaugh 1903); identification of this structure on AT1 remains hypothetical (pvv? On Fig. 6C). Apart from the blood vessels directly associated to the cochlea, a dense network of small channels runs into the thick layer of bone of the promontorium and correspond to bone vascularization channels (Fig. 6A-B); these small channels do not correspond to the location of the pits observed on the mediodorsal aspect of the petrosal bone. 


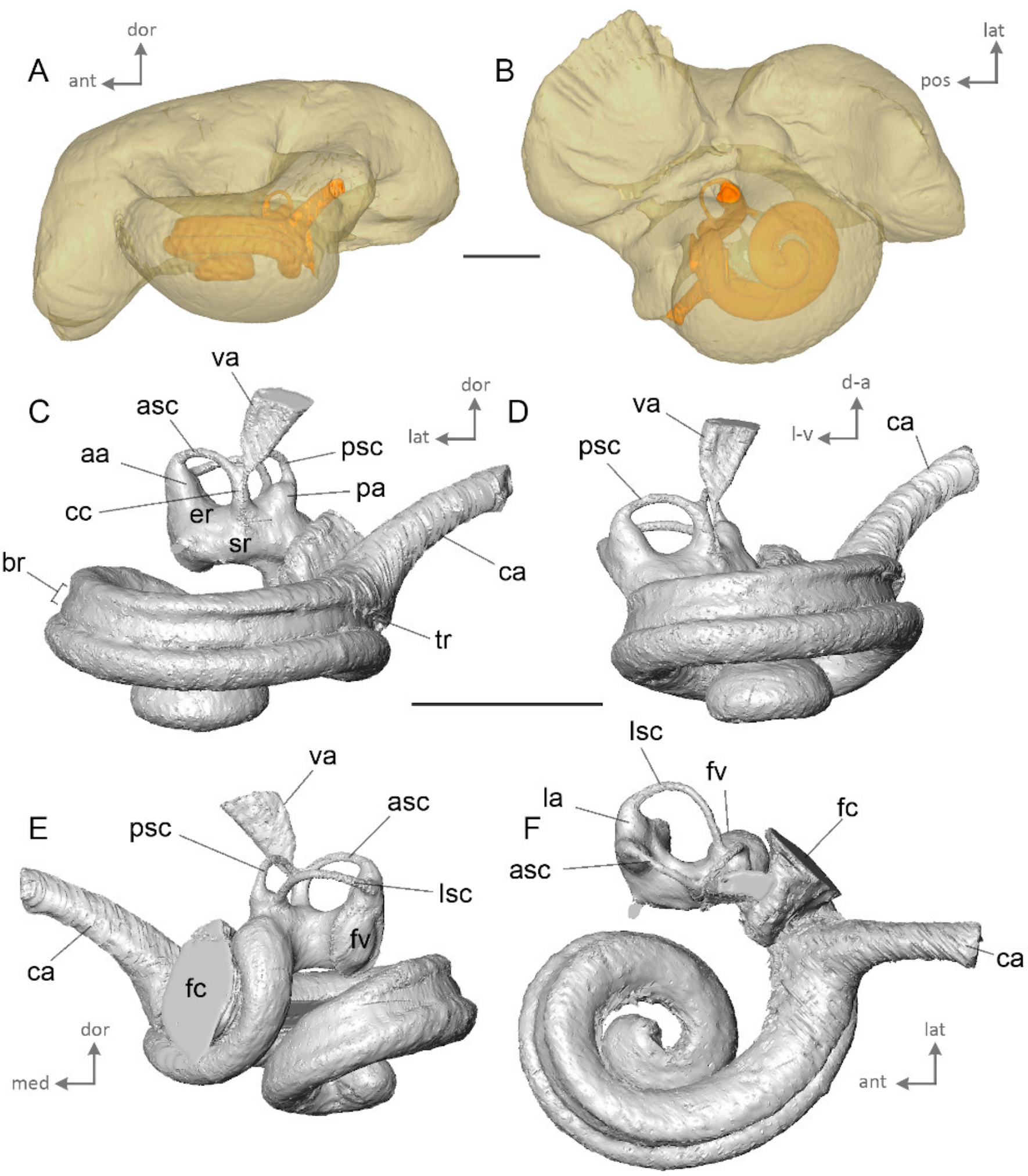

Figure 4. Virtual cast of the bony labyrinth of AT1. A-B, in situ location of the bony labyrinth viewed through a translucent rendering of the petrosal bone in A) medial and B) ventral views. Abbreviations aa, anterior ampulla; asc, anterior semicircular canal; br, basal ridge of the cochlear canal; ca, cochlear aqueduct; cc, common crus; er, elliptical recess; fc, fenestra cochleae; fv, fenestra vestibuli; la, lateral ampulla; lsc, lateral semicircular canal; pa, posterior ampulla; psc, posterior semicircular canal; sr, spherical recess; va, vestibular aqueduct. Scale bars $=5$ $\mathrm{mm}$. 

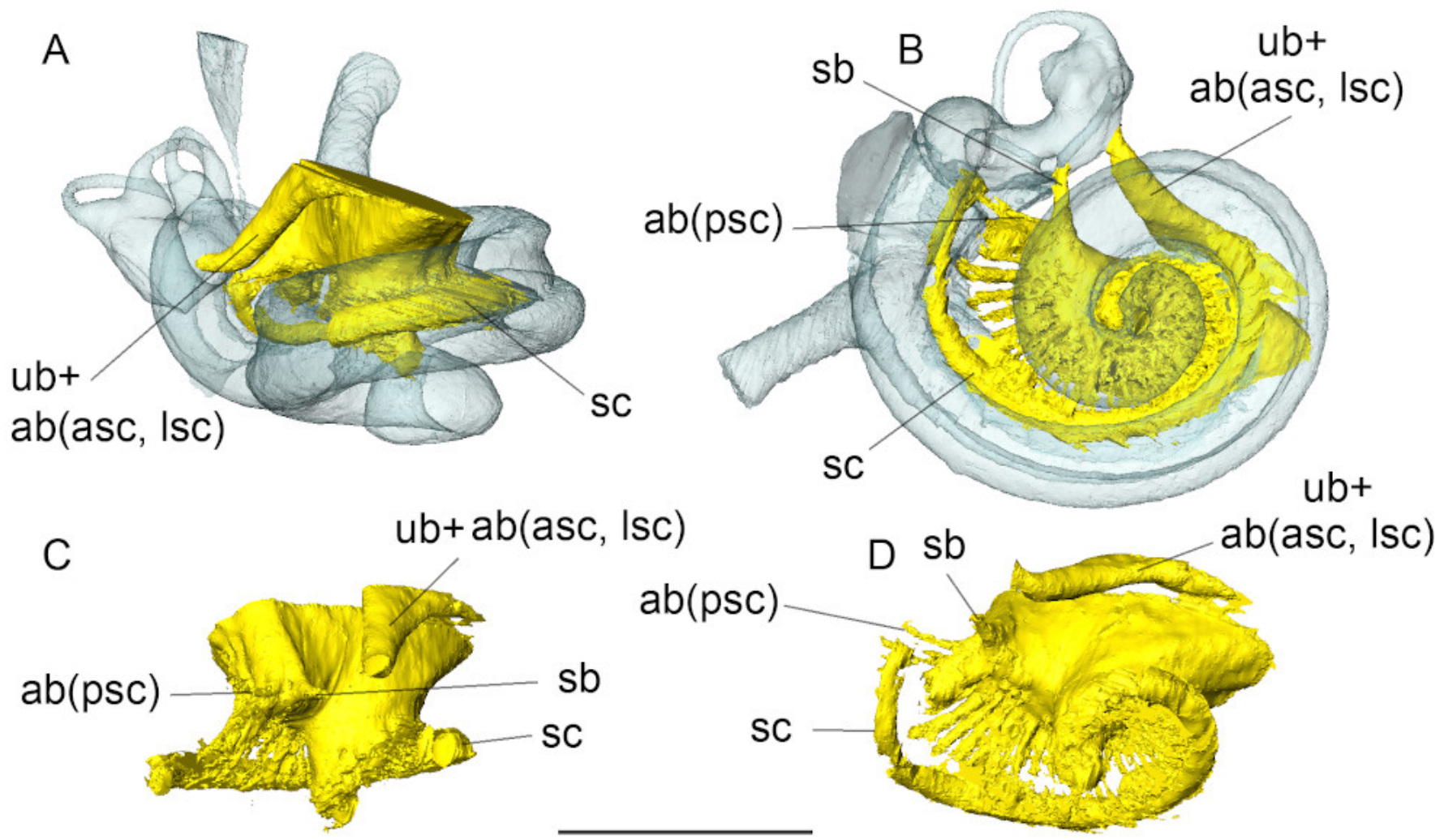

Figure 5. Virtual cast of the vestibulocochlear nerve pathway of AT1. Abbreviations: ab(asc, lsc), ampullar branch to anterior and lateral semicircular canals; ab(psc), ampullar branch to posterior semicircular canal; sb, saccular branch; sc, spiral canal; ub, utricular branch. Scale bar $=5 \mathrm{~mm}$.

\section{DISCUSSION}

\section{Identification of the different components of the inter- nal acoustic meatus in delphinids}

Areas of the internal acoustic meatus are defined by the connections of the nerve fibers that pass through. According to the definitions based on the human skull, the internal acoustic meatus shelters four major areas: i) the anterior inferior cribriform area (including the tractus spiralis foraminosus), ii) the area cribrosa media (orifice for nerves to saccule), iii) the area cribrosa superior (for the passage of the nerves to the utricle and the superior and lateral semicircular ducts), and iv) the endocranial opening of the facial canal (Gray 1918:143). The foramen singulare which transmits the nerves of the ampulla of the posterior semicircular duct, is also one of the main features of the internal acoustic meatus. In cetaceans, the foramen singulare is traditionally recognized as the well-defined foramen located posterior and close to the endocranial opening of the facial canal, clearly separated from the spiral cribriform tract and corresponds to the "vestibular foramen" (e.g. Kellogg 1924, 1928; Kasuya 1973; Mead \& Fordyce 2009:fig. 25a; O'Leary 2010:figs. 83, 93). Mead and Fordyce (2009:116) describe this foramen in Tursiops as the exit of the vestibular nerve. However, in mammals, the foramen singulare is widely recognized specifically as the exit of the nerves coming from the ampulla of the posterior semicircular duct (e.g. Meng \& Fox 1995; Wible
2010; Macrini et al. 2010; Schmitt \& Gheerbrant 2016). Internal investigation of the petrosal and reconstruction of the vestibulocochlear nerve pathways indicates that the foramen identified by Mead and Fordyce (2009) as the foramen singulare does not give passageway to the ampulla of the posterior semicircular canal, but to the saccule, and rather corresponds to the area cribrosa media instead. Luo and Eastman (1995) already noticed the discrepancy between the definition of the foramen singulare and the identification of this foramen in cetaceans. These authors concluded that the "so-called" foramen singulare of cetaceans corresponds instead to "the conduit for the nerve to all semicircular ducts plus the vestibule" (Luo \& Eastman, 1995:436). We precise here the location of the different nerves pathways, and rather interpret the foramen singulare as illustrated by Mead and Fordyce (2009:fig. 25u) and O'Leary (201:figs. 83, 93) as the area cribrosa media. The area cribrosa superior, leading to the vestibule (utricule + anterior and lateral semicircular canals ampullae), would correspond to the oblong opening named "anterior meatal pit" by Mead and Fordyce (2009:fig. 25u). These two areas are often mixed up in the literature, as the location of the area cribrosa media seems to be quite variable from one odontocete species to another (more of less apart from the facial nerve canal). The foramen singulare of AT1, as the case in the sheep (Fig. 7A, C), is somewhat integrated to the foramina of the tractus spiralis foraminosus (first foramen, Fig. 7A-B); this condition might also be observed in other odontocetes. 

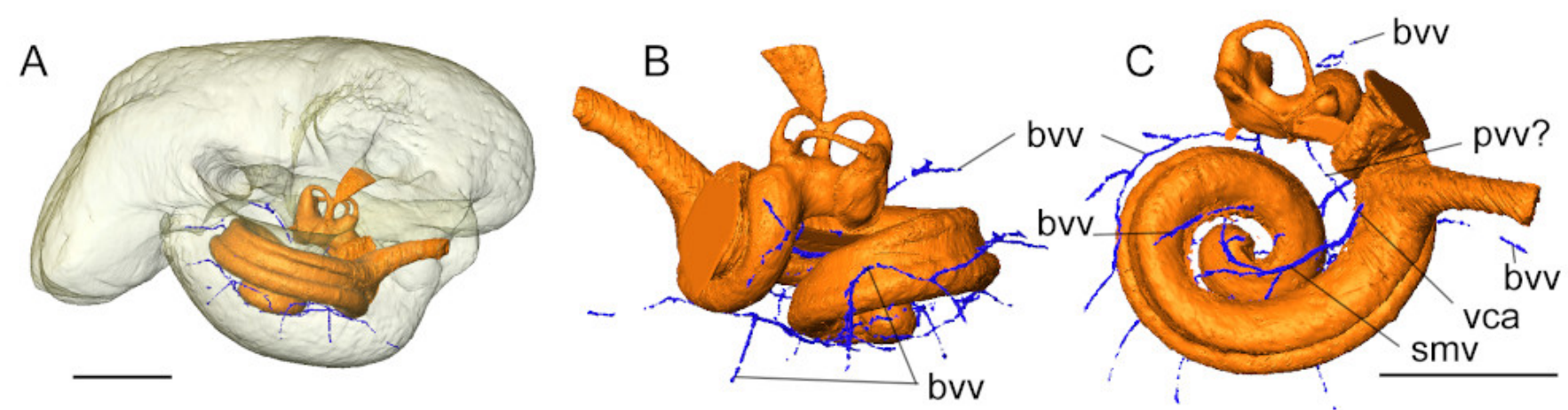

Figure 6. Virtual cast of the bony labyrinth and major vessels surrounding the cochlea in AT1. Abbreviations: bvv, bone vascularization vessels; smv, posterior vestibular vein (vena vestibuli posterior); $\mathbf{s m v}$, spiral modiolar vein; vca, vena of the cochlear aqueduct (= vena canaliculi cochleae). Scale bar $=5 \mathrm{~mm}$.

\section{Referral of the isolated petrosal from ahu Vai Uri}

The petrosal bone found in ahu Vai Uri crematorium shows derived delphinid characters mentioned in the literature (Kasuya 1973; Muizon 1984; Bianucci 2005; Aguirre-Fernandez et al. 2009): i) a short anterior process without anterior bullar facet, ii) rectangular cross-section of the anterior process; iii) $\mathrm{a} \ll$ posterior bullar facet strongly ridged, posterolaterally oriented and parallel to the ventral plane of the bone $\gg$, iv) a globose pars cochlearis v) a relatively large internal acoustic meatus, positioned obliquely on the cochlear portion. Three species of Delphinidae have been observed in the waters of Easter Island: two Globicephalinae Pseudorca crassidens (the false killer whale), and Globicephala sp. (an unidentified pilot whale), and the Delphininae Tursiops truncatus (the bottlenose dolphin). In addition to these species, the delphinine Stenella and Lagenorynchus might be present as well in Easter Island waters judging from their wide geographical distribution (Kaschner et al. 2013). In terms of size, AT1 is too small to be referred to as Pseudorcas crassidens or Globicephala (Kazuya 1973) and is closer in size to the extant Delphininae Stenella coeruleoalba and Delphinus delphis than to Tursiops truncates. This latter species is indeed slightly larger (Table 2-3; Kazuya 1973). Beyond size criterion, AT1 presents three morphological characters which are observed in Stenella coeruleoalba and Delphinus delphis (Bianucci et al. 2009): i) short anterior and posterior processes, ii) a low and wide pars cochlearis, iii) a major axis of the anterior process anteromedially directed. AT1 is also close morphologically to T. truncatus. It however differs from the later by a more massive, shorter anterior process more tightly linked to the pars cochlearis in ventral view, by a slightly larger fenestra cochleae relative to the general size of the promontorium (Table 2-3), and by a smaller vestibular aqueduct. Petrosals of Stenella coeruleoalba and Delphinus delphis can easily be confounded with petrosals of Lagenorynchus (see Bianucci et al. 2009:fig.7 for comparison between the three taxa). But the two former species differ from Lagenorhynchus species (e.g. Lagenorhynchus albirostris, and L. acutus) in being more globose, with less sigmoid outlines, an anterior process wider mediolaterally and shorter anteroposteriorly. The general outline of internal auditory meatus of AT1 is closer to Stenella coeruleoalba than to Delphinus delphis, with a more narrow shape, as illustrated by Bianucci et al. (2009:fig.7). Lastly, the shape of the fenestra vestibuli (and, concurrently, of stapedial footplate) seems to differ between Stenella coeruleoalba and Delphinus delphis, the former being more elongated and the latter more circular. Yet this observation relies on two individuals only (M.J. Mourlam pers. obs.; Lambert et al. 2009:fig.7 for illustration of stapedial footplate of Stenella coeruleoalba) and might be subject to intra-specific variations. Based on these observations, and because intra-specific variation is largely unknown, we consider that AT1 can either be referred to as Stenella or Delphinus. Many petrosal bones of delphinid cetaceans are mentioned from Ahu Naunau (Anakena) and referred to as Delphinus delphis, the common dolphin (Steadman et al. 1994). However, the "diagnostic characters" (Steadman et al. 1994:91) mentioned by the authors are not explicitly cited and the material is not figured. However, it is almost impossible to differentiate Delphininae at the species level based on the external morphology of the petrosal only (Kasuya 1973; Bianucci 1996; Bianucci et al. 2009). Indeed, the petrosal bone of species of the genera Delphinus and Stenella are very close morphologically and are often labelled "Stenella-Delphinus group" (Bianucci 1996). Besides, intraspecific variation is important within both species (Kasuya 1973), further complicating identification of isolated petrosals. Hucle-Gaete et al. (2014) subsequently proposed that the petrosal bones from Ahu Naunau belong to species of the genus Stenella instead, based on nowadays distribution area of the species Delphinus delphis (e.g. Perrin et al. 2009; Jefferson et al. 2008). According to these authors, the latter species never ventures bellow $20^{\circ}$ south latitudes, unlike Stenella species $S$. coeruleoalba, S. attenuatta and S. longirostris which have a wider distribution (Perrin 1975; Perrin et al. 2009; Jefferson et al. 2008). Indeed, the model-based predictive distribution of the marine mammal species of AquaMaps (Kaschner et al. 2013), generated by matching habitat usage of species, against local environmental conditions and knowledge of species' distributions within FAO areas proposes a distribution of Delphinus delphis, excluding the waters of Easter Island. Be it as it may, the past distribution of delphinid species might have been slightly different more than a century ago, and we therefore chose to limit 

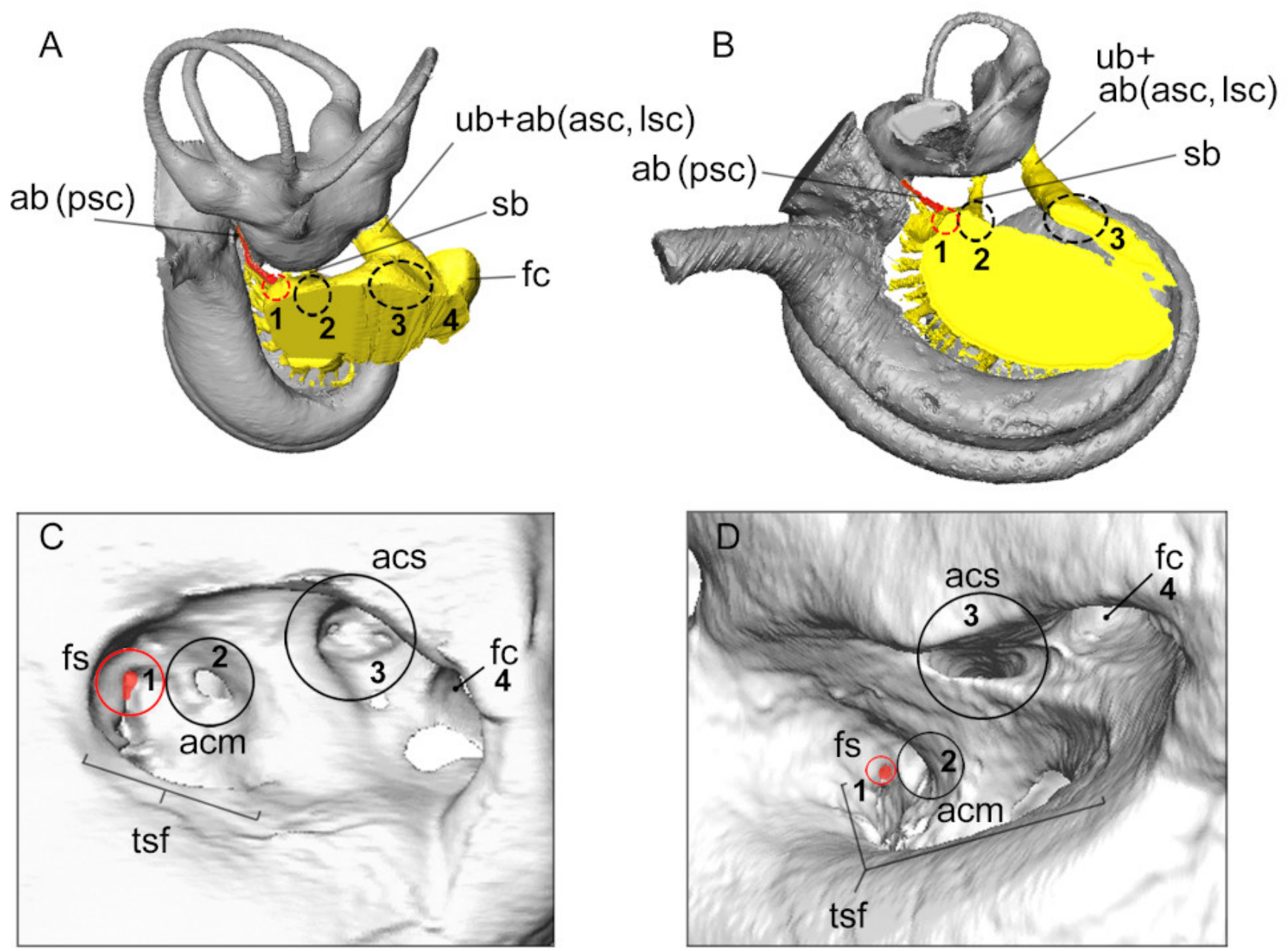

Figure 7. Identification of the different areas of the internal acoustic meatus based on nerves pathways illustrated for the sheep (Ovis aries, A, C) and for the delphinid AT1 (B, D). A and B represent dorsal views of the bony labyrinth (in grey) and its connection with the vestibulocochlear nerve pathways (in yellow); the pathway to the ampulla of the posterior semicircular canal is highlighted in red. Abbreviations: ab(asc, lsc), ampullar branch to anterior and lateral semicircular canals; ab(psc), ampullar branch to posterior semicircular canal; acm, area cribrosa media; acs, area cribrosa superior; fc, facial nerve canal; fs, foramen singulare; sb, saccular branch; tsf, tractus spiralis foraminosus; ub, utricular branch.

our identification of the isolated delphinid petrosal AT1 to the Stenella/Delphinus morphotype.

\section{On the presence of petrosal bone in ahu Vai Uri gravesite (Tahai area), Rapanui and the dolphins}

In Polynesia, cetaceans are by essence of divine nature; for example, the sperm whale is one of the representations of Tangaroa, the god that created the universe and all living creatures (Henry 1988). However, on Easter Island, dolphins were not part of the Rapanui mythology even after the meticulous investigations of the ethnologist Alfred Métraux (1934-35). Indeed, the latter did not mention these animals in its fundamental work of 1940, which gathers a collection of 98 traditional oral tales. Dolphins are not even cited in its very succinct mention of the island fauna. Furthermore, dolphin teeth were never treasured for ornament as it was the case elsewhere in Polynesia; since the discovery of the island in 1772 by the Dutch Roggeveen, no visitor ever mentioned dolphin teeth. Hence, by the time
Alfred Métraux led his investigations, dolphins had long vanished from the preoccupations - and even from the memory - of the Rapanui people. This is also supported by Steadman et al. (1994:91): "Bones of delphinids are rare, in many cases nearly absent, from Easter Island faunal assemblages younger than $\mathrm{c}$. 500 B.P" citing the work of Ayres $(1979,1985)$. However, at the beginning of the island settlement, around the year 1000, dolphins were intensively hunted, as evidenced by the amount of their bones found during the excavation of two digs opened in the Anakena bay (Fig. 1A), at the foot of ahu Naunau. This ahu is located at the bottom of this bay, where it was possible to circle, frighten and kill the dolphins' herds. Their remains are very numerous (over 2900), far ahead those of fish (1682), birds (371), and seals (only 3) (Steadman et al. 1994). In the same place, four rocks were carved or sculpted with dolphins and seals in bas-relief (Fig. 1E). This abundance of remains and symbols, indicates a special link between Anakena and marine mammals. Indeed, the latter represent less than one percent of 
the 2845 representational petroglyphs that were identified on the whole island by Lee (1992). The heavenly bay of Anakena was the residence of the king Hotumatua, first sovereign of the island and whose dynasty ended at the end of the 19th century. This could explain the abundance of dolphin remains, which consumption was maybe reserved to the monarch. It is also possible that, in the religious context of this ceremonial platform, dolphins were offered to gods and ancestors. No other site of the island preserves such a quantity of dolphin remains. Both petrosal yielding sites are not precisely dated, and the ahu Vai Uri crematoria (12-13th century, Shepardson 2013:126) can be either more recent or contemporaneous to the ahu Naunau levels that yielded most of the dolphin remains (10-13 th century, Steadman et al. 1994). Furthermore, the two sites are relatively distant geographically speaking (Fig. 1A) and the people that elaborated ahu Naunau and ahu Vai Uri were therefore most probably different tribes. Yet, the presence of a tympanic bone in the ahu Vai Uri crematorium is consistent with the social importance of this site, and the sacred nature of cetaceans can explain the presence of their remains in crematoria for symbolic reasons, as it is the case in other places around the Pacific Ocean (Koerper et al. 2014). Other crematoria on Rapanui might also contain dolphin remains, but their investigation has not been systematic and remain anecdotal.

\section{ACKNOWLEDGEMENTS}

We are particularly grateful to Fransisco Torres, Director of the Archaeological Museum Father Sebastian Englert in Hanga Roa (Easter Island), for permitting the study and publication of this periotic bone and to Mickaël Mourlam for comments on early version of the manuscript. We acknowledge the MRI platform member of the national infrastructure France-BioImaging supported by the French National Research Agency (ANR-10INBS-04, 'Investments for the future'). We thank L. Costeur and C. Mallet for their review of the manuscript. This is ISE-M publication $\mathrm{n}^{\circ}$ ISEM 2020-031.

\section{BIBLIOGRAPHY}

Aguirre-Fernández G., Barnes L. G., Aranda-Manteca F. J., Fernández-Rivera J. R., 2009. Protoglobicephala mexicana, a new genus and species of Pliocene fossil dolphin (Cetacea; Odontoceti; Delphinidae) from the Gulf of California, Mexico, Boletín de la Sociedad Geológica Mexicana 61, 245-265.

Ayres W. S., 1979. Easter Island fishing. Asian Perspective 22, 61-92.

Ayres W. S., 1985. Easter Island subsistence. Journal de la Société des Océanistes 80, 103-124. https://doi.org/10.3406/j so.1985.2805

Bahn P., Flenley J., 2017. Easter Island, Earth Island: the enigmas of Rapa Nui. Rowman \& Littlefield, New York, London.

Barone R., Bortolami R., 2004. Anatomie comparée des mammifères domestiques: système nerveux central. Neurologie I. Tome sixième. Vigot frères, Paris.
Bianucci G., 1996. The Odontoceti (Mammalia, Cetacea) from Italian Pliocene. Systematics and phylogenesis of Delphinidae. Palaeontographia Italica 83, 73-167

Bianucci G., 2005. Arimidelphis sorbinii a new small killer whale-like dolphin from the Pliocene of Marecchia River (Central eastern Italy) anda phylogenetic analysis of the Orcininae (Cetacea: Odontoceti). RivistaItaliana di Paleontologia e Stratigrafia 111, 329-344.

Bianucci G., Landini W., 2016. Cetacea: An Historical Overview. In: Miller D. L. (Ed), Reproductive Biology and Phylogeny of Cetacea: Whales, Porpoises and Dolphins. CRC Press, pp. 13-46.

Bianucci G., Vaiani S. C., Casati S., 2009. A new delphinid record (Odontoceti, Cetacea) from the Early Pliocene of Tuscany (Central Italy): systematics and biostratigraphic considerations. Neues Jahrbuch für Geologie und Paläontologie, Abhandlungen 254, 275-292. https://doi.org/10.1127/00777749/2009/0018

Churchill M., Martinez-Caceres M., de Muizon C., Mnieckowski J., Geisler J. H., 2016. The origin of high-frequency hearing in whales. Current Biology 26(16), 2144-2149. https: //doi.org/10.1016/j.cub.2016.06.004

Computer generated distribution maps for Stenella attenuata (Pantropical spotted dolphin), with modelled year 2100 native range map based on IPCC A2 emissions scenario. https://ww w.aquamaps.org, version of Aug. 2016. Web. Accessed 6 Dec. 2017.

Doran A. H. G., 1876. Morphology of the mammalian ossicula auditus. Transactions of the Linnean Society, Zoology 1, 371497. https://doi.org/10.1111/j.1096-3642.1878.tb00663.x

Ekdale E. G., 2013. Comparative anatomy of the bony labyrinth (inner ear) of placental mammals. PLoS One 8(6), e66624. https://doi.org/10.1371/journal.pone.0066624

Fleischer G., 1976. Hearing in extinct cetaceans as determined by cochlear structure. Journal of Paleontology 50, 133-152.

Gray H., 1918. Henry Gray's Anatomy of the Human Body. Lea and Febiger, Philadelphia. https://doi.org/10.5962/bhl.title .20311

Henry T., 1988. Tahiti aux Temps Anciens. Publication de la Société des Océanistes n ${ }^{\circ}$, Musée de l'Homme, Paris.

Hucke-Gaete R., Aguayo-Lobo A., Yancovic-Pakarati S., Flores M., 2014. Marine mammals of Easter Island (Rapa Nui) and Salas y Gómez Island (Motu Motiro Hiva), Chile: a review and new records Island. Latin American Journal of Aquatic Research 42(4), 743-751. https://doi.org/10.3856/vol42-issue4fulltext-5

Jefferson T. A., Webber M. A., Pitman R. L., 2008. Marine mammals of the world, a comprehensive guide to their identification. Academic Press, London.

Kaschner K., Rius-Barile J., Kesner-Reyes K., Garilao C., Kullander S., Rees T., Froese R. 2013. AquaMaps. Predicted 
range maps for aquatic species World Wide Web electronic publication, Version, 8, 2013.

Kasuya T., 1973. Systematic consideration of recent toothed whales based on morphology of tympano-periotic bone. The Scientific Reports of the Whale Research Institute (Tokyo) 25, 1-103.

Kellogg R., 1927. Kentriodon pernix, a Miocene porpoise from Maryland. Proceedings of the United States National Museum 69(19), 1-14. https://doi.org/10.5479/si.00963801.69-2645.1

Kellogg R., 1924. A fossil porpoise from the Calvert Formation of Maryland. Proceedings of the United States National Museum 63, 1-58. https://doi.org/10.5479/si.00963801.63-2482.1

Kellogg R. 1928. The history of whales-their adaptation to the life in the water. Quarterly Review of Biology 3, 29-76. https://doi.org/10.1086/394293

Koerper H. C., Hunter G., Snyder I., Cramer J., 2014. Marine Mammal Ear Bones as Charms/Curiosities. Pacific Coast Archaeological Society Quarterly 49, 13-20.

Lambert O., Bianucci G., Post K., 2009. A new beaked whale (Odontoceti, Ziphiidae) from the middle Miocene of Peru. Journal of Vertebrate Paleontology, 29(3), 910-922. https: //doi.org/10.1671/039.029.0304

Lee G., 1992. The Rock Art of Easter Island. Institut of Archaeology, University of California, Los Angeles.

Luo Z., Eastman E. R., 1995. Petrosal and inner ear of a squalodontoid whale: implications for evolution of hearing in odontocetes. Journal of Vertebrate Paleontology 15(2), 431442. https://doi.org/10.1080/02724634.1995.10011239

Macrini T. E., Flynn J. J., Croft D. A., Wyss A. R., 2010. Inner ear of a notoungulate placental mammal: anatomical description and examination of potentially phylogenetically informative characters. Journal of Anatomy 216, 600-610. https://doi.org/10.1111/j.1469-7580.2010.01224.x

Mead J. G., Fordyce R. E., 2009. The therian skull: a lexicon with emphasis on the odontocetes. Smithsonian Contributions to Zoology 627, 1-248. https://doi.org/10.5479/si.00810282.6 27

Meng J., Fox R. C., 1995. Osseous inner ear structures and hearing in early marsupials and placentals. Zoological Journal of the Linnean Society 115(1), 47-71. https://doi.org/10.1006/z jls.1995.0033

Métraux A., 1940. Ethnology of Easter Island. Bernice Pauahi Bishop Museum Publication, Honolulu.

Muizon C. D., 1984. Les vertébrés fossiles de la formation Pisco (Pérou), 2 partie : Les odontocètes (Cetacea, Mammalia) du pliocène inférieur de Sud-Sacaco. Travaux de l'Institut Français des Etudes Andines 27, 1-187.

Mulloy W., 1970. Preliminary report of the restoration of ahu Vai Uri, Easter Island. The Easter Island committee International Fund for Monuments.
Nummela S., Thewissen J. G. M., Bajpai S., Hussain S. T., Kumar K., 2004. Eocene evolution of whale hearing. Nature 430, 776-778. https://doi.org/10.1038/nature02720

Nummela S., Thewissen J. G. M., Bajpai S., Hussain S. T., Kumar K., 2007. Sound transmission in archaic and modern whales: Anatomical adaptations for underwater hearing. The Anatomical Record 290, 716-733. https://doi.org/10.1002/ar. 20528

O'Leary M. A., 2010. An anatomical and phylogenetic study of the osteology of the petrosal of extant and extinct artiodactylans (Mammalia) and relatives. Bulletin of the American Museum of Natural History 335, 1-206. https://doi.org/10.1206/335.1

Orliac C., Orliac M., 2018a. Easter Island, History of the Rapa Nui People. Moai (ed), Hangaroa, Easter Island.

Orliac C., Orliac M., 2018b. Terre et civilisation rapanui. In: Actes Sud (ed), L'Ile de Pâques. Musée Champollion Figeac, Musée Fenaille Rodez, Museum d'Histoire Naturelle Toulouse, pp18-27.

Orliac M. J., Araújo R., Lihoreau F., 2017. The petrosal and bony labyrinth of Diplobune minor, an enigmatic Artiodactyla from the Oligocene of Western Europe. Journal of Morphology 278, 1168-1184. https://doi.org/10.1002/jmor.20702

Perrin W. F., 1975. Distribution and differentiation of populations of dolphins of the genus Stenella in the eastern tropical Pacific. Journal of Fisheries Research Board of Canada 32, 1059-106. https://doi.org/10.1139/f75-125

Perrin W. F, Würsig B., Thewissen J. G. M., 2009. Encyclopedia of Marine Mammals - 2nd edition. Elsevier.

Shambaugh G. E., 1903. The distribution of blood-vessels in the labyrinth of the ear of Sus scrofa domesticus. Decennial Publication of the University of Chicago10, 137-154.

Schmitt A., Gheerbrant E., 2016. The ear region of earliest known elephant relatives: new light on the ancestral morphotype of proboscideans and afrotherians. Journal of anatomy 228(1), 137-152. https://doi.org/10.1111/joa.12396

Shepardson B. L., 2013, Moai a New look at old faces. Rapanui Press, Easter Island.

Steadman D.W, Vargas Casanova P., Cristino Ferrandao C., 1994. Stratigraphy, chronology, and cultural context of an early faunal assemblage from Easter Island. Asian Perspectives 33(1), 79-96.

Wible J. R., 2010. Petrosal anatomy of the nine-banded armadillo, Dasypus novemcinctus Linneaus, 1758 (Mammalia, Xenarthra, Dasypodidae). Annals of the Carnegie Museum 79(1), 1-28. https://doi.org/10.2992/007.079.0101 